\title{
ACRL honors the 2010 award winners, part 1
}

\author{
A recognition of professional achievement
}

\section{Paula T. Kaufman wins Hugh C. Atkinson award}

Paula T. Kaufman, Juanita J. and Robert

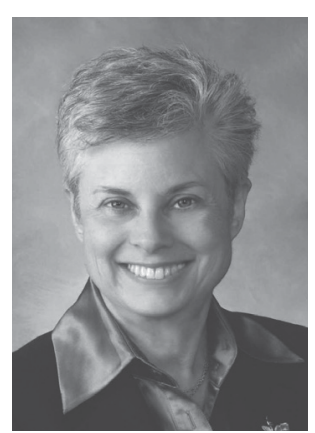

Paula T. Kaufman

E. Simpson dean of libraries and university librarian at the University of Illinois at UrbanaChampaign (UIUC), has been named the winner of the Hugh C. Atkinson Memorial Award. Named in honor of one of the pioneers of library automation, the Atkinson Award recognizes an academic librarian who has made significant contributions in the area of library automation or management, and has made notable improvements in library services or research.

Kaufman will receive a cash award and citation during joint ACRL/Library Leadership and Management Association (LLAMA) Awards Program at the ALA Annual Conference in Washington D.C.

"Paula Kaufman has had a distinguished career characterized by transformative leadership," said Barbara J. Ford, award committee chair and director of the Mortenson Center for International Library Programs and Mortenson distinguished professor at UIUC. "She has created in all her endeavors an atmosphere conducive to experimentation and innovation and has been a strong voice in formulating progressive information policy nationally and internationally."
Kaufman has held a variety of positions over the course of her career. In addition to serving as head of the Business and Economics Library and director of the Library Services group at Columbia University, she was acting head of the East Asian Library in 1982 and acting vice-president for information technology and university librarian (1987-88). During her tenure at Columbia, Kaufman was involved in the development of the university's Scholarly Information Center, a merger of the library and academic information technology. In 1987, Kaufman resisted the FBI's request to report on the reading habits of Columbia library patrons with last names or accents from "hostile countries." Her actions were instrumental in making the FBI's Library Awareness Program public. Kaufman additionally served as dean of libraries at the University of Tennessee-Knoxville from 1988 to 1999.

In her current position at UIUC, Kaufman has worked with the library faculty and staff to re-envision the future, form new alliances, and cultivate an environment of creative problem solving. Under her direction, the library launched a highly successful capital campaign, established a formal preservation and conservation program, led the State of Illinois in digitizing collections, celebrated the library's 11-millionth volume, and addressed the issues of how to support scholarship, and teaching in the digital age through developing new models to deliver 21st-century services. In 2006, the provost

Megan Griffin is ACRL program coordinator, e-mail: mgriffin@ala.org 


\section{Sullivan named Academic/Research Librarian of the Year}

Maureen Sullivan, owner of Maureen Sullivan Associates and professor of practice in the Simmons College Graduate School of Library and Information Science Ph.D. Program in Managerial Leadership, is the 2010 ACRL Academic/Research Librarian of the Year. The award, sponsored by YBP Library Services, recognizes an outstanding member of the library profession who has made a significant national or international contribution to academic/research librarianship and library development.

Sullivan will receive a $\$ 5,000$ award at the joint ACRL/LLAMA Awards Presentation at the ALA Annual Conference.

"Maureen's career has been deeply influential across the spectrum," said Barbara Jenkins, chair of the ACRL Academic/Research Librarian of the Year Award Committee and director for Instruction and Campus Partnerships at the University of Oregon. "Her work in organizational development

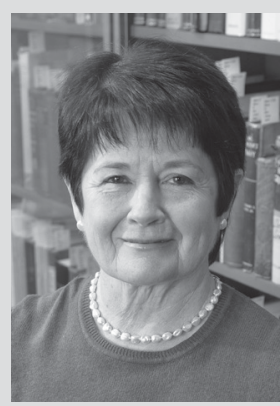

Maureen Sullivan ies and library associations, such as the Texas Library Association and Michigan Library Association. Sullivan was instrumental in the establishment of the ACRL/Harvard Leadership Institute for Academic Librarians, teaching in the institute program for several years and serving as chair from 1999 to 2004.

Sullivan's distinguished record of service to the profession includes serving as ACRL president (1998-99) and as member of the association's Board of Directors (19972000). She served as an ex-officio member of the Harvard Leadership Institute Committee and was a member of both the ACRL 2003 and 2005 National Conference Planning Committees. Sullivan's service to ALA includes co-chairing the Emerging Leaders Initiative (2006-08) and acting as chair of the Minority Fellowship Program Advisory Board (1989-95).

In addition to her well-respected work as an organizational consultant, Sullivan is the author of and strategic planning has had a unique and lasting impact on many individuals and organizations. Almost single handedly, she ushered academic libraries into the world of effective strategic planning-strategic planning that has had a significant impact on how we engage our students, faculty, and others who use our libraries. She has been a model for others in how to reach out, mentor, and engage new professionals and experienced colleagues."

"I am honored to receive this award," said Sullivan. "It is especially meaningful because of all of the opportunities that ACRL and its members have given me throughout my career. I am very fortunate to have received support and guidance from so many colleagues in ACRL and in the profession."

Over the course of her career, Sullivan has made an impact on the profession by providing personnel management, staff development, and organizational development services to a long list of libraries across the country. She has also facilitated leadership development programs for individual librar- several articles on management and organizational development, including "Organization Development in Libraries," published in Library Administration and Management (2004);"The Promise of Appreciative Inquiry in Library Organizations," in Library Trends (2004); and "Total Quality Management in Higher Education," in the Journal of Library Administration (1993).

Prior to founding her consulting practice in 1991, Sullivan served as human resources administrator at the Yale University Library (1983-91) and management training program specialist for the Association of Research Libraries (1980-83). She worked at the University of Maryland-College Park as assistant personnel librarian and assistant director of libraries for personnel (1977-80). She began her appointment in the Simmons College Graduate School of Library and Information Science in 2006.

Sullivan received her BA in History and earned her MLS from the University of Maryland in 1976. from the University of Maryland in 1974 
of UIUC tapped Kaufman to serve as the university's interim chief information officer. In this assignment, she increased communication among technology staff and reconnected the information technology department with the rest of the campus through focusing on its service mission.

She has additionally played key roles in governance and policymaking at a number of organizations, including serving on or leading the boards of directors of the Center for Research Libraries, the Association of Research Libraries, the Council of Library and Information Resources, the Committee on Institutional Cooperation, the Digital Library Federation, and the Society for Scholarly Publishing and Academic Resources Coalition.

Kaufman received her $\mathrm{AB}$ in Economics from

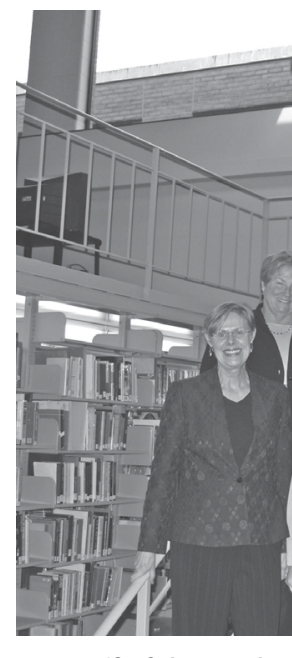

Staff of the Bucks County Community College Library, winner of the community college category.
College, Elmhurst, Illinois; and the Indiana University Bloomington Libraries. Sponsored by ACRL and YBP Library Services, the award recognizes the staff of a college, university, and community college library for programs that deliver exemplary services and resources to further the educational mission of the institution.

"Receiving an Excellence in Academic Libraries Award is a national tribute to a library and its staff for the outstanding services, programs, and leadership they provide to their
Smith College, MBA from the University of New Haven, and MS in Library Service from the School of Library Service at Columbia University.

The Hugh C. Atkinson Award is jointly sponsored by four divisions of ALA: ACRL, the Association for Library Collections and Technical Services (ALCTS), LLAMA, and the Library and Information Technology Association (LITA). The award is funded from an endowment established to honor Hugh C. Atkinson.

\section{ACRL Excellence in Academic Libraries winners announced}

The recipients of the Excellence in Academic Libraries Award are the Bucks County Community College Library, Newtown, Pennsylvania; the A. C. Buehler Library at Elmhurst
Library, winner in the community college category, was cited for its commitment to assessment, collaboration, and development efforts.

"The selection committee was impressed with the library's commitment to areas often underrepresented in community college libraries, including fundraising and development," said Julie Todaro, chair of the 2010 Excellence in Academic Libraries Selection Committee and dean of library services at Austin Community College. "In addition to demonstrating excellent public relations and marketing efforts, the library also provided a solid assessment of programs and services. Their productive partnership with IT was also noteworthy."

"We at Bucks County Community College are delighted to have been selected 


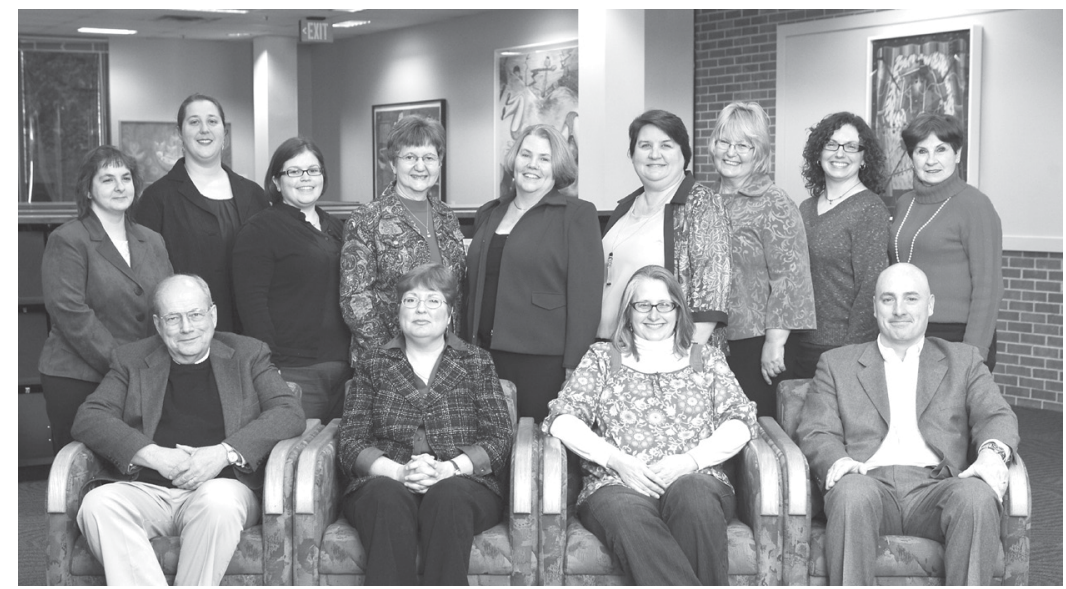

Elmhurst College library staff, winner of the Academic Libraries Award in the community college category.

as the recipient of the ACRL Excellence in Academic Libraries Award in the community college category," said Maureen McCreadie, dean of learning resources. "We have long sought to collaborate, within Learning Resources, across the institution and with other colleges and professional organizations, to provide services in support of the college's mission. That doing what we love, and following our convictions, has led to receiving this prestigious award from the ACRL is a bonus beyond our imagining. Recognition from ACRL is truly an honor."

The A. C. Buehler Library at Elmhurst College, winner of this year's award in the college category, impressed the selection committee with its strategic planning initiatives and focus on student engagement.

"Buehler Library demonstrated an excellent program for outreach to classroom faculty and articulated the link between library planning and activities to the institution's strategic plan," Todaro noted. "The selection committee admired the integration of gaming into student engagement activities, along with the library's focus on student development programs and services."

"We are delighted to have been selected for this year's award," said Susan Swords Steffen, director of the library at Elmhurst

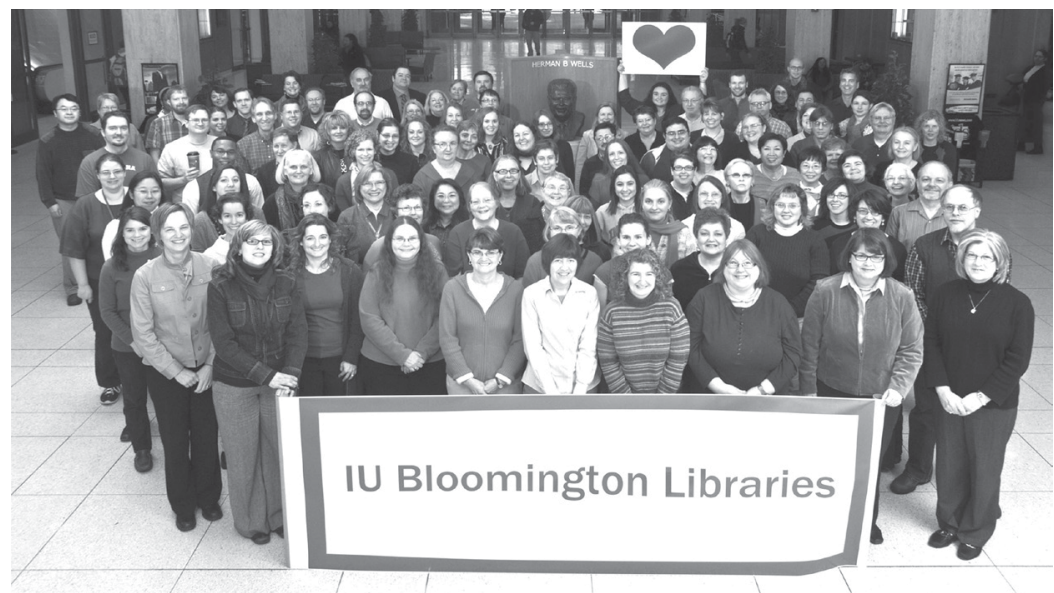

IU Bloomington Libraries, winner of the Academic Libraries Award in the university category. 
College. "We have been successful in creating an excellent library because everyone is committed to flexibility, risk taking, pitching in when and where they are needed, and embracing new challenges and opportunities as they arise. I am proud and pleased to work with this fine group of library professionals who have worked hard to create an excellent library for the students and faculty of Elmhurst College: a library that is central to the life of the college and a model for small college libraries."

Indiana University (IU) Bloomington Libraries, winner of the university category, was noted for its commitment to implementing a wide range of changes to improve student learning.

"The library's wonderful six-year commitment to, and process for, library programs and service changes impressed the selection committee," said Todaro. "They demonstrate excellent leadership by focusing on student engagement activities and student learning. Their excellent assessment programs include a clear sense of value, importance, and impact of library programs and services."

"Receiving this honor is a testament to the dedication and hard work of our librarians and staff at every level," said Carolyn Walters, interim Ruth Lilly dean of university libraries at IU Bloomington. "At a time when the nature of libraries is changing so swiftly and dramatically, this award is welcome recognition that we are not only responding to these changes in a positive way, but also leading by example."

Each winning library will receive $\$ 3,000$ and a plaque, to be presented at an award ceremony held on each recipient's campus. The winners also will receive special recognition at the ACRL/LLAMA joint awards program during the ALA Annual Conference.

\section{Abbott named Routledge Distance Learning Librarianship Conference Sponsorship Award winner}

Thomas E. Abbott, dean of libraries and distance learning at the University of MaineAugusta, has been named the recipient of the
Routledge Distance Learning Librarianship Conference Sponsorship Award. This annual award, sponsored by Routledge/Taylor \& Francis Group and administrated by the ACRL Distance Learning Section (DLS), honors an ACRL member working in the field of, or contributing to the success of, distance learning librarianship or related library service in higher education.

Routledge/Taylor \& Francis Group will

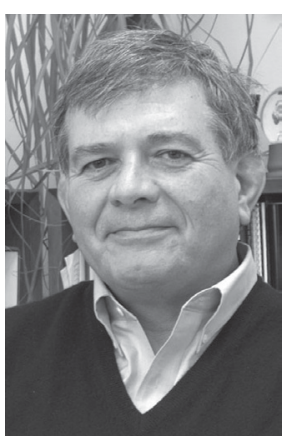

Thomas E. Abbott present the $\$ 1,200$ award and plaque at the ALA Annual Conference.

"Thomas Abbott has been a leader in the field of distance learning for well over 20 years," said Jerilyn Marshall, chair of the DLS award committee and head of the Reference and Instructional Services Department at the University of Northern Iowa's Rod Library. "The award committee was impressed with his record of achievement in administrative leadership, distance learning program development, and mentoring. For many years he has been an active participant and leader in DLS, including service as chair and as a member of many section committees."

Prior to becoming dean of libraries and distance learning at the University of MaineAugusta in 2005, Abbott was dean of libraries and instructional support at the same institution from 1998 to 2005. He was chair of the University of Maine System Library Directors' Council from 2003 to 2008, and served as director of library/learning resources at the University of Maine-Augusta from 1986 to 1998. Since 1990, Thomas has served on numerous DLS committees and was chair of the section (1996-97).

Abbott's many professional accomplishments include serving as the project administrator and primary author of a new Associate Degree Program in Library and Information Services, the University of Maine-Augusta's 
first degree program designed specifically for Web-based delivery worldwide for library support staff. He simultaneously coordinated statewide satellite delivery of a master's degree in Library and Information Science program from the University of South Carolina. The program is now in its fourth cohort.

Abbott additionally developed the concept and program for the statewide Off-Campus Library Services for students and faculty in the Educational Network of Maine/University College Services, which is now administered by his university for the University of Maine System.

Since 2004, Abbott has served as an editorial board member for the Journal of Library and Information Services in Distance Learning. He was an editorial/advisory board member for Educational Pathways, a monthly electronic newsletter about the latest developments in higher education distance learning and teaching (2003-05). His publications include "Filling the Void: An Academic Library's Experience Developing an Associate Degree in Library and Information Technology for Distance Education Students," in CERL News (November 1997) and author of the book chapter "Distance Education and Off-Campus Library Services: Challenges for the Accreditation Process and Librarians" in Challenge and Practice of Academic Accreditation, A Handbook for Information Professionals, published in 1994 by Greenwood Publishing Group.

Abbott received his BA in Sociology from the University of Maine-Orono in 1972, and his Master of Education in Counseling and Administration from the University of Southern Maine in 1976. He earned his PhD in Higher Education Management, with a minor in Organizational Studies from Boston College in 1989.

\section{Madsen receives Doctoral Dissertation Fellowship award}

Christine Madsen, librarian and DPhil candidate, Oxford Internet Institute (OII), University of Oxford, has been awarded the ACRL
Doctoral Dissertation Fellowship for her proposal, "Library Futures: Building a New Knowledge Architecture in Academic Libraries." The fellowship, sponsored by Thomson Reuters, fosters research in academic librarianship by encouraging and supporting dissertation research.

The award of $\$ 1,500$ and $a$ plaque will be presented during the joint ACRL/LLAMA Awards Program at the ALA Annual Conference.

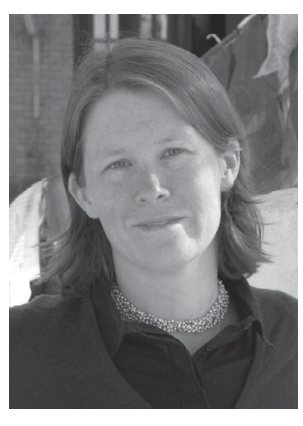

Christine Madsen

"This project stood out in a very competitive field because of its originality and timeliness," said Brian Doherty, chair of the selection committee and dean of the Jane Bancroft Cook Library at the University of South Florida-Sarasota-Manatee.

"Madsen's concept of examining digitization projects in the humanities from the perspective of impact on the way scholarship is done opens up a new and important field of research."

Madsen came to OII from the Harvard University Library where, as manager of the Open Collections Program, she designed a methodology and procedures for digitizing Harvard's historical library collections and opening them to the world. Prior to her appointment at Harvard, she served at the Art and Architecture Library at the University of California-San Diego (UCSD) as manager of digital image reserves and slide production manager. She also served as a technical consultant on several large-scale digitization and metadata mapping projects, including ArtSTOR. Recently, she has worked with One Laptop per Child in an effort to create a model for identifying and aggregating content for young learners in developing countries.

Madsen received her BA in Visual Arts with a concentration in the History of Photography from UCSD in 1995. In 2002, she earned her MLS from San Jose State University. $\boldsymbol{n}$ 